\title{
Concurrent gene alterations with EGFR mutation and treatment efficacy of EGFR-TKIs in Chinese patients with non-small cell lung cancer
}

\author{
Wentao Hu', Yahui Liư ${ }^{2}$, Jian Chen ${ }^{1}$ \\ ${ }^{1}$ Department of Thoracic Surgery, Ningbo First Hospital, Ningbo, Zhejiang 315000, P.R. China \\ ${ }^{2}$ Key Laboratory of Ningbo, Ningbo First Hospital, Ningbo, Zhejiang 315000, P.R. China \\ Correspondence to: Yahui Liu, email: ningboxwk@163.com \\ Keywords: epidermal growth factor receptor, tyrosine kinase inhibitor, non-small cell lung cancer, concurrent gene, efficacy \\ Received: November 10, $2016 \quad$ Accepted: January 11, $2017 \quad$ Published: February 15, 2017 \\ Copyright: Hu et al. This is an open-access article distributed under the terms of the Creative Commons Attribution License \\ (CC-BY), which permits unrestricted use, distribution, and reproduction in any medium, provided the original author and source \\ are credited.
}

\section{ABSTRACT}

Purpose: We investigated the frequency of concurrent genes in EGFR-mutant non-small cell lung cancer patients and determined its value in predicting the efficacy of EGFR-TKIs treatment.

Methods: Three hundred and twenty patients, who harbored EGFR activating mutations and received EGFR-TKIs treatment, were examined for another eight genes including KRAS, NRAS, PIK3CA, BRAF, and HER2 mutations and ALK, ROS1, and RET fusion genes based on reverse transcription PCR. Progression-free survival and overall survival with EGFR-TKIs treatment were evaluated using Kaplan-Meier methods and compared between different patients using log-rank tests.

Results: Twenty-one $(6.6 \%)$ of 320 EGFR mutant samples with additional gene alterations were identified. The most common concurrent gene was PIK3CA mutation $(n=9)$, followed by EML4-ALK rearrangement $(n=6)$, HER2 mutation $(n=3), R E T$ rearrangement $(n=1), \operatorname{ROS1}$ rearrangement $(n=1)$ and $\operatorname{KRAS}$ mutation $(n=1)$. Patients with single EGFR mutation had a significantly longer progression-free survival than those with concurrent genes (10.9 vs. 6.0 months, $P=0.002)$. Among the 21 cases, patients with PIK3CA mutation had the longest median progression-free survival (7.6 months), followed by ALK rearrangement (5.0 months) and other gene types (1.2 months). No overall survival difference was found between patients with single EGFR mutation and concurrent gene alterations ( 21.0 vs.17.6 months, $P=0.17$ ).

Conclusion: We demonstrated that concurrent gene alterations occurred in some patients with EGFR mutations. Concurrent gene alterations decreased the efficacy of EGFR-TKIs.

\section{INTRODUCTION}

Epidermal growth factor receptor $(E G F R)$ mutations occur in about $40 \%$ to $50 \%$ of lung adenocarcinoma patients of East Asian descent [1, 2]. The median progression-free survival (PFS) is approximately 9 to 13 months and the objective response rate of $60 \%$ to $70 \%$ in patients carrying EGFR mutations treated with EGFR-TKIs [3-6].

Drug resistance is a big issue for most patients with clinically evident non-small cell lung cancer (NSCLC).
T790M mutation, MET amplification and PIK3CA mutations contributed to secondary resistance to EGFR-TKIs and several new drugs targeting resistance have emerged [7-12]. Primary resistance is another challenge in clinical practice, however, the mechanism is not well investigated currently. Coexistent genetic alterations in cancer-driving genes, i.e., KRAS mutations, PTEN loss and BIM polymorphisms were identified to be associated with primary resistance for EGFR-TKIs treatment [13-14]. But, most studies focused on concurrent $A L K$ and EGFR mutations [15-16]. Other genes such as PIK3CA and HER2 were not well reported. The 
efficacy of EGFR-TKIs for NSCLC patients with coexisting genetic alterations remains unclear.

In the present study, we used multiple gene screening of 320 NSCLC patients harboring EGFRsensitive mutations and evaluated the frequency of concomitant genetic alterations, further to investigate the efficacy of EGFR-TKIs treatment in these patients.

\section{RESULTS}

\section{Patient characteristics}

The characteristics of the 320 patients are shown in Table 1. Twenty-one patients with EGFR mutation that harbored a concurrent driver gene were identified. The clinical and molecular characteristics of the 21 patients are shown in Table 2. There were 11 male and 10 female with a median age of 62 years. Twenty patients presented with a histology of adenocarcinoma and one typical of adenosquamous carcinoma. Seven patients included former or current smokers and 14 were never-smokers. No clinical or pathological differences were observed between patients with single $E G F R$ mutation and those who harbored concurrent genes (Table 3).

\section{Gene results}

Among the 320 patients with EGFR mutations, 157 were with deletion in exon 19, 142 with L858R point mutation in exon 21,13 with L861Q or G719X mutation in exon 18, and 8 with other mutations (three of T790M mutation, four of 20 insertion and one of S768I). All the 320 patients were analyzed for KRAS, NRAS, PIK3CA, $B R A F, H E R 2$ mutations and $A L K, R O S 1$, and RET fusion genes. Coexisting mutations or fusions were identified in 21 patients $(6.6 \%)$. This analysis included PIK3CA mutation (n $=9,42.9 \%)$, followed by $E M L 4-A L K$ rearrangement $(\mathrm{n}=$ 6, 28.6\%), HER2 mutation ( $\mathrm{n}=3,14.3 \%), K R A S$ mutation ( $\mathrm{n}=1,4.8 \%), R E T$ rearrangement $(\mathrm{n}=1,4.8 \%), R O S 1$ rearrangement $(\mathrm{n}=1,4.8 \%), B R A F$ mutation $(\mathrm{n}=0,0 \%)$, and NRAS mutation $(\mathrm{n}=0,0 \%)$. The coexisting mutations are listed in Table 2. Among the 21 patients, 14 included those with deletion in exon 19, 4 with L858R mutation in exon 21, one with G719X mutation in exon 18 and one with L861Q mutation in exons 21. More frequency of coexisting mutations in deletion in exon 19 was observed than L858R mutation in exon 21 ( $8.9 \%$ vs. $2.8 \%, P=0.028)$.

\section{Efficacy analysis}

One hundred and eighty-six patients with single EGFR mutation showed partial responses (62.2\%), one with complete response $(0.3 \%)$ and 67 showed stable disease $(22.4 \%)$; 46 patients had progressive disease. The ORR was $62.5 \%$ and DCR was $84.9 \%$, In patients with concurrent gene alterations, the ORR and DCR were
$47.6 \%$ and $66.7 \%$, respectively. The efficacy comparisons are shown in Table 4.

The median PFS in all the 320 patients was 10.8 months (95\%CI, 9.9-11.6). The PFS in the group with single EGFR mutation and concurrent gene alterations group were 10.9 months $(95 \% \mathrm{CI}, 10.0-11.5)$ and 6.0 months $(95 \% \mathrm{CI}, 3.8-8.2)$, respectively $(P=0.002)$ (Figure 1). The median PFS in patients carrying PIK $3 C A, A L K$ and other genes were 7.6 months, 5.0 months and 1.2 months, respectively $(P=0.880)$. No PFS difference was found between $E G F R / P I K 3 C A$ mutation and $E G F R /$ other gene concurrent patients $(P=0.881)$.

The PFS in the group with single EGFR exon 19 deletion mutation and concurrent gene alterations group were 11.4 months $(95 \% \mathrm{CI}, 10.4-12.5)$ and 6.0 months $(95 \% \mathrm{CI}, 4.1-7.8)(P=0.001)$. The PFS in the group with single EGFR exon 21 L858R mutation and concurrent gene alterations group were 9.5 months $(95 \% \mathrm{CI}, 8.3-10.8)$ and 2.2 months $(95 \% \mathrm{CI}, 0.0-5.9)(P=0.009)$.

A multivariate Cox regression model was constructed with the incorporation of age, gender, performance status, and mutation types (single vs.concurrence) to evaluate the PFS. Mutation types $(P=0.032)$ remained as independent factor for PFS.

The median survival time of all the patients was 21.0 months (95\%CI,19.5-25.4). The OS in the single EGFR mutation and concurrent gene alterations group was 21.0 months, and 17.6 months, respectively $(P=0.170)$ (Figure 2).

\section{DISCUSSION}

Our data demonstrated that the frequency of coalterations between EGFR and other driver genes (ALK, ROS1, RET, PIK3CA, BRAF, KRAS, NRAS, BRAF) in NSCLC was $6.6 \%$. Patients of NSCLC without concurrent gene had a significantly longer PFS with EGFR-TKIs treatment. To the best of our knowledge, this is the first study demonstrating the presence of EGFR mutations concurrent with multple gene mutations and the therapeutic efficacy of EGFR-TKIs.

Although driver genes in NSCLC were reported to be mutually exclusive [18-20], several studies have shown that driver genes occur concurrently with EGFR mutations [21-22]. In the current cohort, the frequency of concurrent EGFR/ALK mutations is $1.9 \%$, which is consistent with previous studies reporting in the range of $0.0 \%$ to $6 \%$ [23-24]. The phosphatidylinositol 3-kinase (PI3K) plays an important role in cancer cell metabolism and proliferation. PIK3CA mutations are commonly found in a variety of cancers, with a prevalence of about $2 \%$ to $4 \%$ in NSCLC [22-25]. PIK3CA mutations co-exist mostly with KRAS mutations in lung cancer. However, the underlying mechanisms involving EGFR mutation are unclear [22]. A report by Chaft et al. included 23 lung adenocarcinoma patients with PIK3CA and 3 with EGFR concurrent mutations [26]. In the present study, $2.8 \%$ of NSCLC patients in China with EGFR mutations harbored 
Table 1: Demographic characteristics of the study population $(n=320)$

\begin{tabular}{|c|c|}
\hline & Number \\
\hline \multicolumn{2}{|l|}{ Gender } \\
\hline Male & 176 \\
\hline Female & 144 \\
\hline \multicolumn{2}{|l|}{ Age } \\
\hline Range & $31-78$ \\
\hline Median & 59 \\
\hline$<60$ & 196 \\
\hline$\geq 60$ & 124 \\
\hline \multicolumn{2}{|l|}{ Smoking status } \\
\hline Never & 197 \\
\hline Former/current & 123 \\
\hline \multicolumn{2}{|l|}{ Histology } \\
\hline Adenocarcinoma & 302 \\
\hline No-adenocarcinoma & 18 \\
\hline \multicolumn{2}{|l|}{ Stage at EGFR-TKI treatment } \\
\hline IIIB & 5 \\
\hline IV & 315 \\
\hline \multicolumn{2}{|l|}{ Surgical history } \\
\hline Yes & 135 \\
\hline No & 185 \\
\hline \multicolumn{2}{|c|}{ Type of EGFR-activating mutation } \\
\hline Exon 19 deletion & 157 \\
\hline Exon 21 L858R & 142 \\
\hline Exon 18 G719X & 8 \\
\hline Exon $21 \mathrm{~L} 861 \mathrm{Q}$ & 5 \\
\hline Other mutation & 8 \\
\hline \multicolumn{2}{|l|}{ Concurrent mutation } \\
\hline Yes & 21 \\
\hline No & 299 \\
\hline \multicolumn{2}{|l|}{ EGFR-TKIs } \\
\hline Erlotinib & 43 \\
\hline Gefitinib & 56 \\
\hline Icotinib & 220 \\
\hline Afatinib & 1 \\
\hline \multicolumn{2}{|l|}{ EGFR-TKIs in which line } \\
\hline First-line & 76 \\
\hline Second-line & 189 \\
\hline Third-line or further-line & 55 \\
\hline \multicolumn{2}{|c|}{ Performance score at EGFR-TKI treatment } \\
\hline $0-1$ & 249 \\
\hline $2-3$ & 71 \\
\hline
\end{tabular}


Table 2: Clinical profile of concurrent gene alterations in non-small cell lung cancer patients

\begin{tabular}{|c|c|c|c|c|c|c|c|c|c|}
\hline Case & Gender & Age & $\begin{array}{c}\text { Smoking } \\
\text { history }\end{array}$ & Histology & Gene type & $\begin{array}{l}\text { EGFR-TKI/ } \\
\text { which line }\end{array}$ & Response & $\begin{array}{l}\text { PFS/ } \\
\text { month }\end{array}$ & $\begin{array}{c}\text { OS/ } \\
\text { month }\end{array}$ \\
\hline 1 & Male & 44 & Yes & Adenocarcinoma & 19del+PIK3CA & $\begin{array}{l}\text { Gefitinib/ } \\
\text { Second }\end{array}$ & PR & 10.4 & 18.7 \\
\hline 2 & Male & 75 & No & Adenocarcinoma & 19del+PIK3CA & Icotinib/Third & PR & 11.2 & 20.3 \\
\hline 3 & Female & 62 & No & Adenocarcinoma & L861Q+PIK3CA & Icotinib/Second & PD & 1.2 & 12.5 \\
\hline 4 & Male & 59 & Yes & Adenocarcinoma & 19del+PIK3CA & Icotinib/Third & PR & 7.6 & 17.6 \\
\hline 5 & Female & 75 & No & Adenocarcinoma & 19del+PIK3CA & Gefitinib/Third & PR & 6 & 15.5 \\
\hline 6 & Male & 62 & No & Adenocarcinoma & L858R+PIK3CA & Icotinib/Second & $\mathrm{SD}$ & 9.5 & 16.7 \\
\hline 7 & Male & 67 & Yes & Adenosquamous & 19del+PIK3CA & Icotinib/Third & PR & 9.7 & 20.5 \\
\hline 8 & Female & 66 & No & Adenocarcinoma & G719X+PIK3CA & Icotinib/Second & $\mathrm{PD}$ & 2 & 12.1 \\
\hline 9 & Male & 44 & Yes & Adenocarcinoma & 19del+PIK3CA & $\begin{array}{c}\text { Gefitinib/ } \\
\text { Second }\end{array}$ & PR & 7.5 & 17.6 \\
\hline 10 & Female & 64 & No & Adenocarcinoma & L858R+ALK & Gefitinib/First & SD & 4.5 & 16.5 \\
\hline 11 & Female & 40 & No & Adenocarcinoma & 19del+ALK & Icotinib/Second & PR & 8.9 & $24.3+$ \\
\hline 12 & Male & 64 & No & Adenocarcinoma & 19del+ALK & Erlotinib/First & PR & 14 & 28.7 \\
\hline 13 & Female & 59 & No & Adenocarcinoma & 19del+ALK & Icotinib/Third & $\mathrm{PD}$ & 1.2 & 19.5 \\
\hline 14 & Male & 45 & No & Adenocarcinoma & 19del+ALK & Erlotinib/First & $\mathrm{SD}$ & 5 & 18.6 \\
\hline 15 & Male & 64 & Yes & Adenocarcinoma & 19del+ALK & Icotinib/Second & $\mathrm{SD}$ & 6.5 & 17.7 \\
\hline 16 & Female & 65 & No & Adenocarcinoma & 19del++HER2 & Icotinib/Third & $\mathrm{PD}$ & 1.2 & 12.5 \\
\hline 17 & Female & 69 & No & Adenocarcinoma & L861Q+HER2 & Icotinib/Second & $\mathrm{PD}$ & 1 & 6.5 \\
\hline 18 & Female & 50 & No & Adenocarcinoma & 19del+HER2 & Icotinib/Second & PR & 14.4 & 17.7 \\
\hline 19 & Female & 60 & No & Adenocarcinoma & $\mathrm{L} 858 \mathrm{R}+\mathrm{RET}$ & Gefitinib/Third & $\mathrm{PD}$ & 2.2 & 10.2 \\
\hline 20 & Male & 63 & Yes & Adenocarcinoma & L858R+KRAS & Erlotinib/First & PD & 1 & 6.5 \\
\hline 21 & Male & 49 & Yes & Adenocarcinoma & 19del+ROS1 & Erlotinib/First & PR & 24 & $47.8+$ \\
\hline
\end{tabular}

PIK3CA mutations. With the emerging of next generation sequencing(NGS), more and more concurrent genes were observed. One study reported by Kim et al. showed that compound EGFR mutation was frequently detected with co-mutations of EGFR actionable genes by NGS [27].

The frequency of concomitant EGFR mutations and other driver genes except $A L K$ and $P I K 3 C A$ in NSCLC were not well known, and elucidated the case report [2829]. In our cohort, three patients with $H E R 2$, one with $R E T$, one with $K R A S$ and one with ROS1 gene were found, while, no $B R A F$ and $N R A S$ were found coexisting with EGFR mutation.

The efficacy of EGFR-TKIs treatment in patients with concomitant EGFR mutations and other driver genes is not well studied due to their rarity. The median PFS of EGFR-TKIs was 11.2 months in Yang's study including 10 patients with co-existing EGFR/ALK mutations [30].
Relative levels of phospho-EGFR predicted the efficacy of EGFR-TKI in patients with $E G F R / A L K$ mutations. In the current series, the median PFS of six patients with concurrent $E G F R / A L K$ mutations was 5.0 months, which is shorter than in Yang's study. The small sample may explain the difference of our cases and previous studies. A concurrent PIK3CA mutation did not decreased the efficacy of EGFR-TKIs in Eng, et al. study [31], which including 10 patients of $E G F R / P I K 3 C A$ co-altered. In contrast, in present cohort, we found that patients' concurrent PIK3CA mutation may decrease the PFS and objective response, consistent with previous preclinical studies [32]. Different from Eng, et al. study, our results indicated no significantly OS difference between patients with single EGFR mutation and concurrent genes. One reason may contribute to the small sample of patients with concurrent genes. Another reason may due to the influence 
Table 3: Comparative analysis of clinical profile between single EGFR mutation and concurrent gene alteration patients

\begin{tabular}{|c|c|c|c|}
\hline Characteristics & Single EGFR mutation & Concurrent alteration & $P$ \\
\hline Gender & & & 0.80 \\
\hline Male & 165 & 11 & \\
\hline Female & 134 & 10 & \\
\hline Age & & & 0.02 \\
\hline$<60$ & 188 & 8 & \\
\hline$\geq 60$ & 111 & 13 & \\
\hline Smoking status & & & 0.62 \\
\hline Never & 183 & 14 & \\
\hline Former/current & 116 & 7 & \\
\hline Histology & & & 0.73 \\
\hline Adenocarcinoma & 288 & 20 & \\
\hline No-adenocarcinoma & 11 & 1 & \\
\hline $\begin{array}{l}\text { Stage at EGFR-TKI } \\
\text { treatment }\end{array}$ & & & 0.75 \\
\hline IIIB & 5 & 0 & \\
\hline IV & 294 & 21 & \\
\hline EGFR mutation type & & & 0.57 \\
\hline $\begin{array}{l}\text { Exon } 19 \text { deletion+Exon } 21 \\
\text { L858R }\end{array}$ & 280 & 19 & \\
\hline Other types & 19 & 2 & \\
\hline $\begin{array}{l}\text { Performance score at EGFR- } \\
\text { TKI treatment }\end{array}$ & & & 0.20 \\
\hline $0-1$ & 235 & 14 & \\
\hline $2-3$ & 64 & 7 & \\
\hline
\end{tabular}

Table 4: Clinical efficacy comparison of EGFR-TKI in single EGFR mutation and concurrent gene alterations

\begin{tabular}{lccc}
\hline Best response & $\begin{array}{c}\text { Single EGFR mutation } \\
(\mathbf{n = 2 9 9})\end{array}$ & $\begin{array}{c}\text { Concurrent gene } \\
\text { alterations }(\mathbf{n = 2 1})\end{array}$ & $\boldsymbol{P}$ \\
\hline CR & $1(0.3 \%)$ & $0(0.0 \%)$ & 0.79 \\
PR & $186(62.2 \%)$ & $10(47.6 \%)$ & 0.18 \\
SD & $67(22.4 \%)$ & $4(19.0 \%)$ & 0.25 \\
PD & $46(15.4 \%)$ & $7(33.3 \%)$ & 0.03 \\
ORR & $62.5 \%$ & $47.6 \%$ & 0.17 \\
DCR & $84.9 \%$ & $66.7 \%$ & 0.03 \\
Median PFS(month) & 10.9 & 6.0 & 0.002 \\
Median OS(month) & 21.0 & 17.6 & 0.17 \\
\hline
\end{tabular}


of additional treatment after failure of EGFR-TKI therapy. In our cohort, four of six patients with $A L K$ rearrangement received the crizotinib treatment after failure of EGFRTKI treatment and three with partial response. However, no further treatment data were provided in Eng, et al study. The influence of concurrent genes to overall survival should be validated with large number patients in the future studies.

The most remarkable shortcomings of our study were related to the small sample size of concurrent genes. Secondly, MET amplification, mutation and other genes like NTRK1 and PTEN, which may coexist with EGFR

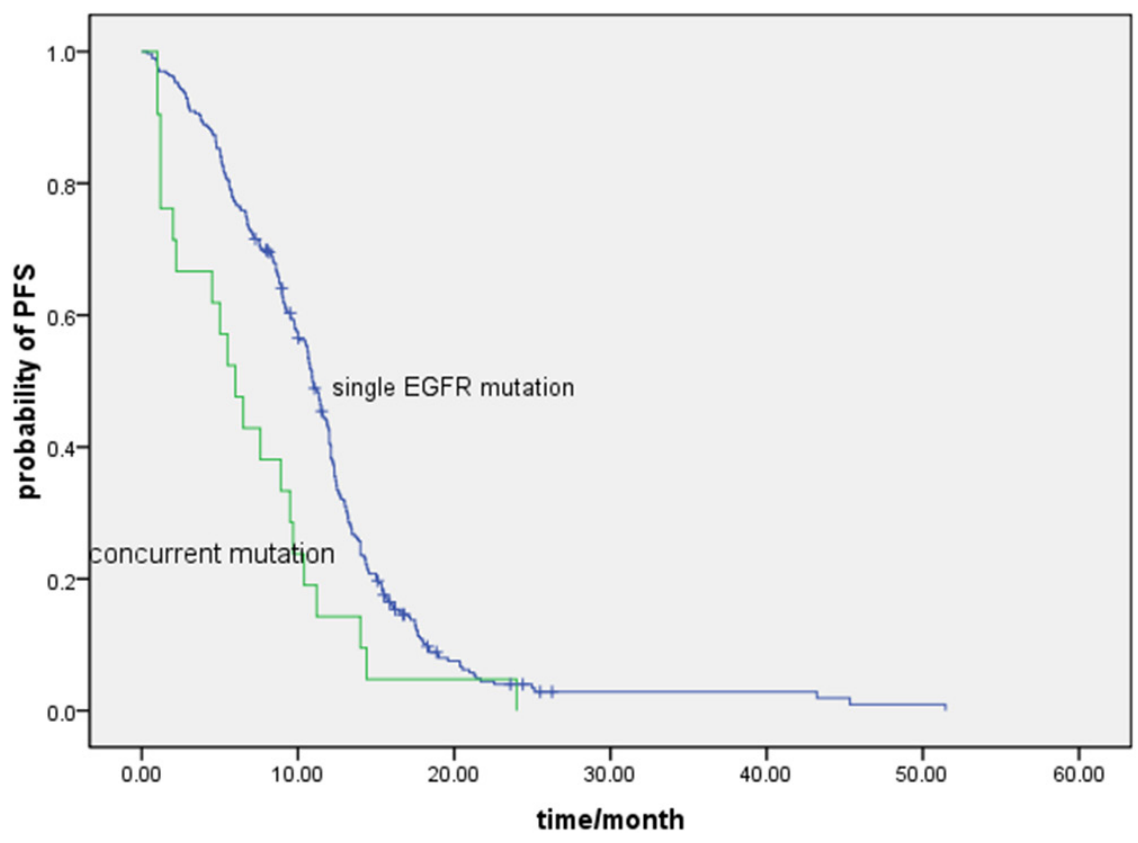

Figure 1: Comparison of progression free survival with EGFR-TKI treatment between single EGFR mutation and concurrent gene alterations patients $(10.9$ vs.6.0 months, $P=0.002)$.

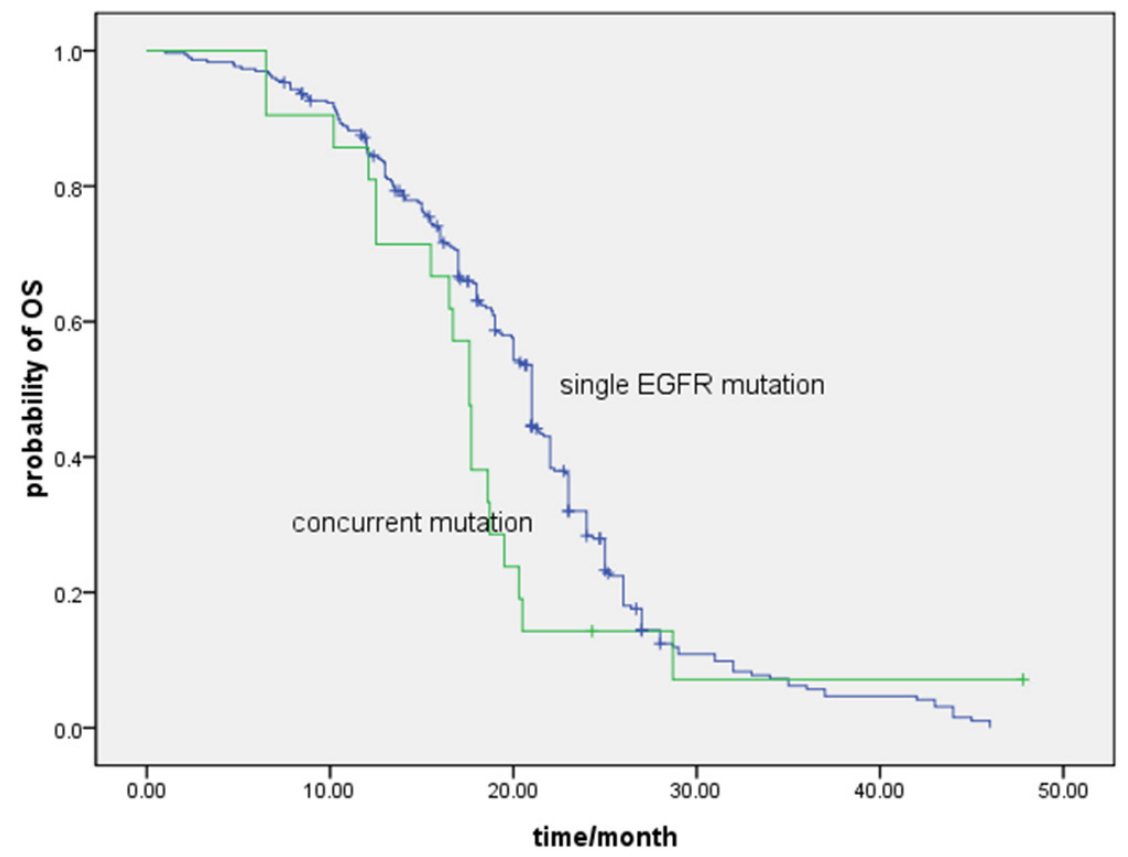

Figure 2: Comparison of overall survival with EGFR-TKI treatment between single EGFR mutation and concurrent gene alterations patients $(21.0$ months vs.17.6 months, $P=0.170)$. 
gene in EGFR-TKIs treatment-naive samples, were not detected in current study for lack of sufficient tumor tissues. Thirdly, only five cases were treated with inhibitor focus on the coexisting gene (four with ALK and one with ROS1), so, the clinical efficacy of further treatment after failure of EGFR-TKIs could not be fully evaluated. Lastly, age and performance score imbalance were found between the single EGFR mutation and coexisting gene group, which may influence the outcome analysis in present study (Table 3). However, as the first study investigating the role of multiple genes in EGFR mutant patients, the findings are clinically meaningful.

In conclusion, this is the first study to focus on the predictive value of concurrent EGFR and other mutations in driver genes for EGFR-TKIs treatment. It suggests that some of the genes concomitant with EGFR mutation might decrease the efficacy of EGFR-TKIs treatment. In the future, prospective studies must validate the efficacy of different therapies for concurrent gene alterations NSCLC patients.

\section{MATERIALS AND METHODS}

\section{Patient selection}

Four hundred and twenty-nine consecutive patients who carried sensitive EGFR mutations and underwent EGFR-TKIs treatment for advanced NSCLC at Ningbo First Hospital were screened between 2009 and 2013. Of the 429 patients, 109 were ineligible because of a lack of tumor tissue for analysis of 8 genes. In 320 patients with identified genes, 135 patients had formalin-fixed paraffinembedded (FFPE) tumor tissue blocks obtained at the time of surgical resection, 157 were tissue biopsies, and 38 with malignant effusion. Among the 320 samples, 270 of the samples used for 8 genes detection were obtained from the remaining tissues of EGFR gene analysis and 50 were reobtained before EGFR-TKIs treatment. Ethics Committee of Ningbo First Hospital approved this study and a written informed consent was obtained from each participant.

\section{Gene detection}

Amplification refractory mutation system (ARMS)based EGFR mutation detection kit (Amoy, Xiamen, China) was used to detect $E G F R$ mutation in all patients. The ARMS kit is able to detect 29 mutations: three in exon 18 (G719A, G719C and G719S; the kit was unable to distinguish between these subtypes, which are referred to as G719X hereafter), 19 deletions in exon 19, two mutations in exon 20 (T790M, S768I), three insertions in exon 20, and two mutations in exon 21 (L858R, L861Q).

A microscopy was used to patients with EGFRmutated ensure the tumor tissues analyzed had more than $20 \%$ tumor contents. Genomic DNA or RNA was extracted from tumor tissues according to standard protocols
(RNeasy Mini Kit, and QiAamp DNA Mini Kit, Qiagen, Hilden, Germany). Briefly, the isolated RNA samples were used for reverse transcription into cDNA using Revert Aid First Strand cDNA Synthesis Kit (Fermentas, St Leon-Rot, Germany). Either genomic DNA or cDNA was used for PCR amplification and sequencing. HER2, KRAS, NRAS, $B R A F$, and $P I K 3 C A$ were PCR amplified using genomic DNA. Cycle sequencing of the purified PCR products was carried out with PCR primers using the commercially available ADx Mutation Detection Kits (Amoy, Xiamen, China).

The $A L K, R O S 1$, and RET fusion mRNAs were detected by PCR with fusion gene detection kit (Amoy, Xiamen, China). In brief, total RNA was extracted with QiagenRNeasy FFPE Kit. The mRNA was reversetranscribed to cDNA at $42^{\circ} \mathrm{C}$ for 1 hour. $\beta$-actin was used as the internal control. The RT-PCR conditions were as follows: an initial denaturation at $95^{\circ} \mathrm{C}$ for 5 minutes, followed by $95^{\circ} \mathrm{C}$ for 25 seconds, $64^{\circ} \mathrm{C}$ for 20 seconds, and $72^{\circ} \mathrm{C}$ for 20 seconds to ensure the specificity; and 31 cycles at $93^{\circ} \mathrm{C}$ for 25 seconds, $60^{\circ} \mathrm{C}$ for 35 seconds, $72^{\circ} \mathrm{C}$ for 20 seconds were performed for data collection and sensitivity analysis, as detailed in previous study [17]. All of the partners which could be detected were attached as Supplementary Table 1.

\section{Efficacy evaluation}

Tumors were evaluated during EGFR-TKIs treatment every 8 weeks, or were evaluated early when significant signs of progression appeared. Objective tumor responses were determined according to the Response Evaluation Criteria in Solid Tumors (RECIST 1.1). Objective responses rate (ORR) includes complete response $(\mathrm{CR})$, partial response $(\mathrm{PR})$, stable disease (SD) and progressive disease (PD). Disease control rate (DCR) is defined as the addition of objective response and stabilization rates $(\mathrm{CR}+\mathrm{PR}+\mathrm{SD})$.

\section{Statistical analysis}

Survival curves were calculated using the KaplanMeier method from the start of diagnosis of advanced NSCLC until death or last follow-up. PFS of EGFRTKIs was defined as the time from EGFR-TKIs therapy to documented progression or death from any cause. Statistical analysis was performed with the SPSS 16 software (Chicago, IL, US). $P<0.05$ was considered statistically significant. The median follow-up period was 23.5 months (7.5-65) and the last follow-up was on April $31,2015$.

\section{CONFLICTS OF INTEREST}

The authors declare no conflicts of interest. 


\section{FUNDING}

This work was supported by Grants from the Natural Science Foundation project of Ningbo (No. 2016A610168).

\section{REFERENCES}

1. Shi Y, Au JS, Thongprasert S, Srinivasan S, Tsai CM, Khoa MT, Heeroma K, Itoh Y, Cornelio G, Yang PC. A prospective, molecular epidemiology study of EGFR mutations in Asian patients with advanced non-small-cell lung cancer of adenocarcinoma histology (PIONEER). J Thorac Oncol. 2014; 9:154-62.

2. Lee CK, Wu YL, Ding PN, Lord SJ, Inoue A, Zhou C, Mitsudomi T, Rosell R, Pavlakis N, Links M, Gebski V, Gralla RJ, Yang JC. Impact of Specific Epidermal Growth Factor Receptor (EGFR) Mutations and Clinical Characteristics on Outcomes After Treatment With EGFR Tyrosine Kinase Inhibitors Versus Chemotherapy in EGFRMutant Lung Cancer: A Meta-Analysis. J Clin Oncol. 2015; 33:1958-65.

3. Han JY, Park K, Kim SW, Lee DH, Kim HY, Kim HT, Ahn MJ, Yun T, Ahn JS, Suh C, Lee JS, Yoon SJ, Han $\mathrm{JH}$, et al. First-SIGNAL: first-line single-agent iressa versus gemcitabine and cisplatin trial in never-smokers with adenocarcinoma of the lung. J Clin Oncol. 2012; 30:1122-28.

4. Zhou C, Wu YL, Chen G, Feng J, Liu XQ, Wang C, Zhang S, Wang J, Zhou S, Ren S, Lu S, Zhang L, Hu C, et al. Erlotinib versus chemotherapy as first-line treatment for patients with advanced EGFR mutation-positive non-smallcell lung cancer (OPTIMAL, CTONG-0802): a multicentre, open-label, randomised, phase 3 study. Lancet Oncol. 2011; 12:735-42.

5. Mitsudomi T, Morita S, Yatabe Y, Negoro S, Okamoto I, Tsurutani J, Seto T, Satouchi M, Tada H, Hirashima T, Asami K, Katakami N, Takada M, et al, and West Japan Oncology Group. Gefitinib versus cisplatin plus docetaxel in patients with non-small-cell lung cancer harbouring mutations of the epidermal growth factor receptor (WJTOG3405): an open label, randomised phase 3 trial. Lancet Oncol. 2010; 11:121-28.

6. Mok TS, Wu YL, Thongprasert S, Yang CH, Chu DT, Saijo N, Sunpaweravong P, Han B, Margono B, Ichinose Y, Nishiwaki Y, Ohe Y, Yang JJ, et al. Gefitinib or carboplatinpaclitaxel in pulmonary adenocarcinoma. N Engl J Med. 2009; 361:947-57.

7. Sequist LV, Waltman BA, Dias-Santagata D, Digumarthy S, Turke AB, Fidias P, Bergethon K, Shaw AT, Gettinger S, Cosper AK, Akhavanfard S, Heist RS, Temel J, et al. Genotypic and histological evolution of lung cancers acquiring resistance to EGFR inhibitors. Sci Transl Med. $2011 ; 3: 75 \mathrm{ra} 26$.
8. Yu HA, Arcila ME, Rekhtman N, Sima CS, Zakowski MF, Pao W, Kris MG, Miller VA, Ladanyi M, Riely GJ. Analysis of tumor specimens at the time of acquired resistance to EGFR-TKI therapy in 155 patients with EGFR-mutant lung cancers. Clin Cancer Res. 2013; 19:2240-47.

9. Suda K, Mizuuchi H, Maehara Y, Mitsudomi T. Acquired resistance mechanisms to tyrosine kinase inhibitors in lung cancer with activating epidermal growth factor receptor mutation-diversity, ductility, and destiny. Cancer Metastasis Rev. 2012; 31:807-14.

10. Jänne PA, Yang JC, Kim DW, Planchard D, Ohe Y, Ramalingam SS, Ahn MJ, Kim SW, Su WC, Horn L, Haggstrom D, Felip E, Kim JH, et al. AZD9291 in EGFR inhibitor-resistant non-small-cell lung cancer. N Engl J Med. 2015; 372:1689-99.

11. Sequist LV, Soria JC, Goldman JW, Wakelee HA, Gadgeel SM, Varga A, Papadimitrakopoulou V, Solomon BJ, Oxnard GR, Dziadziuszko R, Aisner DL, Doebele RC, Galasso C, et al. Rociletinib in EGFR-mutated non-small-cell lung cancer. N Engl J Med. 2015; 372:1700-09.

12. Jardim DL, Tang C, Gagliato DM, Falchook GS, Hess K, Janku F, Fu S, Wheler JJ, Zinner RG, Naing A, Tsimberidou AM, Holla V, Li MM, et al. Analysis of 1,115 patients tested for MET amplification and therapy response in the MD Anderson Phase I Clinic. Clin Cancer Res. 2014; 20:6336-45.

13. Kim GW, Song JS, Choi CM, Rho JK, Kim SY, Jang SJ, Park YS, Chun SM, Kim WS, Lee JS, Kim SW, Lee DH, Lee JC. Multiple resistant factors in lung cancer with primary resistance to EGFR-TK inhibitors confer poor survival. Lung Cancer. 2015; 88:139-46.

14. Lee JK, Shin JY, Kim S, Lee S, Park C, Kim JY, Koh Y, Keam B, Min HS, Kim TM, Jeon YK, Kim DW, Chung DH, et al. Primary resistance to epidermal growth factor receptor (EGFR) tyrosine kinase inhibitors (TKIs) in patients with non-small-cell lung cancer harboring TKI-sensitive EGFR mutations: an exploratory study. Ann Oncol. 2013; 24:2080-87.

15. Won JK, Keam B, Koh J, Cho HJ, Jeon YK, Kim TM, Lee SH, Lee DS, Kim DW, Chung DH. Concomitant ALK translocation and EGFR mutation in lung cancer: a comparison of direct sequencing and sensitive assays and the impact on responsiveness to tyrosine kinase inhibitor. Ann Oncol. 2015; 26:348-54.

16. Baldi L, Mengoli MC, Bisagni A, Banzi MC, Boni C, Rossi G. Concomitant EGFR mutation and ALK rearrangement in lung adenocarcinoma is more frequent than expected: report of a case and review of the literature with demonstration of genes alteration into the same tumor cells. Lung Cancer. 2014; 86:291-95.

17. Wu C, Zhao C, Yang Y, He Y, Hou L, Li X, Gao G, Shi J, Ren S, Chu H, Zhou C, Zhang J, Schmid-Bindert G. High Discrepancy of Driver Mutations in Patients with NSCLC 
and Synchronous Multiple Lung Ground-Glass Nodules. J Thorac Oncol. 2015; 10:778-83.

18. Zhang Y, Sun Y, Pan Y, Li C, Shen L, Li Y, Luo X, Ye T, Wang R, Hu H, Li H, Wang L, Pao W, Chen H. Frequency of driver mutations in lung adenocarcinoma from female never-smokers varies with histologic subtypes and age at diagnosis. Clin Cancer Res. 2012; 18:1947-53.

19. Sun Y, Ren Y, Fang Z, Li C, Fang R, Gao B, Han X, Tian W, Pao W, Chen H, Ji H. Lung adenocarcinoma from East Asian never-smokers is a disease largely defined by targetable oncogenic mutant kinases. J Clin Oncol. 2010; 28:4616-20.

20. Li H, Pan Y, Li Y, Li C, Wang R, Hu H, Zhang Y, Ye T, Wang L, Shen L, Sun Y, Chen H. Frequency of well-identified oncogenic driver mutations in lung adenocarcinoma of smokers varies with histological subtypes and graduated smoking dose. Lung Cancer. 2013; 79:8-13.

21. Li S, Li L, Zhu Y, Huang C, Qin Y, Liu H, Ren-Heidenreich L, Shi B, Ren H, Chu X, Kang J, Wang W, Xu J, et al. Coexistence of EGFR with KRAS, or BRAF, or PIK3CA somatic mutations in lung cancer: a comprehensive mutation profiling from 5125 Chinese cohorts. Br J Cancer. 2014; 110:2812-20.

22. Scheffler M, Bos M, Gardizi M, König K, Michels S, Fassunke J, Heydt C, Künstlinger H, Ihle M, Ueckeroth F, Albus K, Serke M, Gerigk U, et al. PIK3CA mutations in non-small cell lung cancer (NSCLC): genetic heterogeneity, prognostic impact and incidence of prior malignancies. Oncotarget. 2015; 6:1315-26. doi: 10.18632/ oncotarget.2834.

23. Zhang X, Zhang S, Yang X, Yang J, Zhou Q, Yin L, An S, Lin J, Chen S, Xie Z, Zhu M, Zhang X, Wu YL. Fusion of EML4 and ALK is associated with development of lung adenocarcinomas lacking EGFR and KRAS mutations and is correlated with ALK expression. Mol Cancer. 2010; 9:188.

24. Sasaki T, Koivunen J, Ogino A, Yanagita M, Nikiforow S, Zheng W, Lathan C, Marcoux JP, Du J, Okuda K, Capelletti M, Shimamura T, Ercan D, et al. A novel ALK secondary mutation and EGFR signaling cause resistance to ALK kinase inhibitors. Cancer Res. 2011; 71:6051-60.

25. Rekhtman N, Paik PK, Arcila ME, Tafe LJ, Oxnard GR, Moreira AL, Travis WD, Zakowski MF, Kris MG, Ladanyi
M. Clarifying the spectrum of driver oncogene mutations in biomarker-verified squamous carcinoma of lung: lack of EGFR/KRAS and presence of PIK3CA/AKT1 mutations. Clin Cancer Res. 2012; 18:1167-76.

26. Chaft JE, Arcila ME, Paik PK, Lau C, Riely GJ, Pietanza MC, Zakowski MF, Rusch V, Sima CS, Ladanyi M, Kris MG. Coexistence of PIK3CA and other oncogene mutations in lung adenocarcinoma-rationale for comprehensive mutation profiling. Mol Cancer Ther. 2012; 11:485-91.

27. Kim EY, Cho EN, Park HS, Hong JY, Lim S, Youn JP, Hwang SY, Chang YS. Compound EGFR mutation is frequently detected with co-mutations of actionable genes and associated with poor clinical outcome in lung adenocarcinoma. Cancer Biol Ther. 2016; 17:237-45.

28. Hirai F, Takenoyama M, Taguchi K, Toyozawa R, Inamasu E, Toyokawa G, Yoshida T, Shiraishi Y, Takenaka T, Yamaguchi M, Ushijima C, Seto T, Takeo S, Ichinose Y. Experience with erlotinib in lung adenocarcinoma harboring a coexisting KIF5B-RET fusion gene and EGFR mutation: report of a rare case. J Thorac Oncol. 2014; 9:e37-39.

29. Tajima S, Koda K. Transition between morule-like and solid components may occur in solid-predominant adenocarcinoma of the lung: report of 2 cases with EGFR and KRAS mutations. Int J Clin Exp Pathol. 2015; 8:7475-81.

30. Yang JJ, Zhang XC, Su J, Xu CR, Zhou Q, Tian HX, Xie Z, Chen HJ, Huang YS, Jiang BY, Wang Z, Wang BC, Yang $\mathrm{XN}$, et al. Lung cancers with concomitant EGFR mutations and ALK rearrangements: diverse responses to EGFR-TKI and crizotinib in relation to diverse receptors phosphorylation. Clin Cancer Res. 2014; 20:1383-92.

31. Eng J, Woo KM, Sima CS, Plodkowski A, Hellmann MD, Chaft JE, Kris MG, Arcila ME, Ladanyi M, Drilon A. Impact of concurrent PIK3CA mutations on response to EGFR tyrosine kinase inhibition in EGFR-mutant lung cancers and on prognosis in oncogene-driven lung adenocarcinomas. J Thorac Oncol. 2015; 10:1713-19.

32. Engelman JA, Mukohara T, Zejnullahu K, Lifshits E, Borrás AM, Gale CM, Naumov GN, Yeap BY, Jarrell E, Sun J, Tracy S, Zhao X, Heymach JV, et al. Allelic dilution obscures detection of a biologically significant resistance mutation in EGFR-amplified lung cancer. J Clin Invest. 2006; 116:2695-706. 